\title{
Improving the perspectives on quality of life for adolescents with cerebral palsy by medical textile
}

\author{
DOI: 10.35530/IT.071.01.1779
}

\section{ABSTRACT - REZUMAT}

\section{Improving the perspectives on quality of life for adolescents with cerebral palsy by medical textile}

The quality of life (QoL) can be defined as the individual's perception of his own existence, both from the point of view of the physical integrity of the body's structures and of functionality too, as well as of the activity, respectively the capability of performing tasks, and of the participation, regarded as the involvement in the life situations.

From a medical perspective, the quality of life assessment is an indicator that provides important information, closely related to the improvement of the health status and the effectiveness of the therapeutic-rehabilitative interventions. The textile sector by research-development activities and by its numerous projects and accomplishments in the biomaterials, biotechnologies and medical device, showed a steady focus, in close relation to the medical field, on disabled persons' quality of life and on the facilitation of their social and professional integration.

The aim of rehabilitative interventions is to obtain the best possible physical and mental health, allowing each patient to build social relationships with family and community and, on the other hand, to acquire professional skills for being able to find a suitable job which will improve his wellbeing and quality of life.

This paper presents how adolescents with cerebral palsy and their parents/caregivers perceive the quality of life of the adolescent taking into consideration the activity limitations and the participation restrictions.

The results of the study showed the existence of discrepancies between adolescents' and parents' reports regarding the QoL, with adolescents' reporting a higher QoL than did their parents.

Optimism and positive thinking can be seen as augmentation factors of the therapeutic interventions' effects by increasing the adolescent's involvement in the rehabilitation process, having as direct benefit early and better results.

Keywords: health, education, participation, social inclusion, wellbeing

\section{Îmbunătățirea percepțiilor asupra calității vieții adolescenților cu paralizie cerebrală prin textile medicale}

Calitatea vieții poate fi definită ca percepția individului asupra propriei existențe, atât din punct de vedere al integrității fizice a structurilor organismului și al funcționalității corpului, cât și al activității, respectiv al capacității de a îndeplini sarcini, și al participării, privită ca implicare în situațiile de viață.

Din perspectivă medicală, evaluarea calității vieții reprezintă un indicator care furnizează informații importante, strâns legate de îmbunătățirea stării de sănătate și de eficacitatea intervențiilor terapeutice de recuperare. Sectorul textil, prin activitățile sale de cercetare-dezvoltare și numeroase proiecte și realizări în domeniul biomaterialelor, biotehnologiilor și dispozitivelor medicale, a arătat un interes permanent, în strânsă legătură cu domeniul medical, pentru a îmbunătăți calitatea vieții persoanelor cu dizabilități și pentru a le facilita incluziunea socială și profesională.

Scopul tratamentului de recuperare este de a obține cea mai bună stare de sănătate fizică și psihică posibilă, care să permită fiecărui pacient, pe de o parte, să construiască relații sociale cu familia și cu comunitatea și, pe de altă parte, să dobândească abilități profesionale pentru a putea găsi un loc de muncă adecvat, care să ducă la o creștere a prosperității și calității vieții.

Acest articol prezintă modul în care adolescenții cu paralizie cerebrală și părinții/aparținătorii acestora percep calitatea vieții adolescentului luând în considerare limitările activității și restricțiile de participare.Rezultatele studiului au arătat că adolescenții, spre deosebire de părinții/aparținătorii lor, sunt mai optimiști în ceea ce privește percepția calității vieții lor. În acelaşi timp, există diferenţe semnificative ale valorilor indicatorilor de percepţie cu privire la calitatea vieţii, atunci când luăm în considerarea tipologia afecţiunilor cerebrale investigate. Optimismul și gândirea pozitivă pot fi priviți ca factori de amplificare a efectelor intervențiilor terapeutice prin creșterea implicării adolescentului în procesul de recuperare, având ca beneficiu direct apariția precoce a unor rezultate mai bune.

Cuvinte-cheie: sănătate, educație, participare, incluziune socială, bunăstare

\section{INTRODUCTION}

International Classification of Functioning, Disability and Health - Children \& Youth Version (ICF-CY) defines "mental functions of attention, memory and perception... activities involving play, learning, family life and education" as "components of health and health-related components of well-being (o.n.HRQoL)" [1]. Thus, health refers not only to Body Functions and Structures (physiological functions of body systems and, respectively anatomical components of the body), but to Activities (execution of tasks) and Participation (involvement in life situations), too. 
World Health Organization (WHO) defines health as "... state of complete physical, mental, and social well-being not merely the absence of disease..." and QoL as "an individual's perception of their position in life in the context of the culture and value systems in which they live ... in relation to their goals, expectations ... concerns" [2].

A new and very humane vision of $\mathrm{WHO}$ - according to the level and expectations of a developed and civilized society - considers that the problematic situational ensemble represented by the handicap of a disabled person is primarily a result of the society/community's (for now) inability to have compensate the individual for invalidity so that, their activity and participation, socio-economic, are (almost) unchanged. In this respect, some authors recommend to use the term "disabled child" instead of "child with a disability", considering that society and environment are the ones that disables them [3].

Information technology (IT) field/tech sector/tech industry, represented by the virtual infrastructure and the related communication possibilities, is an opportunity to implement this humanitarian vision of nondiscrimination and social inclusion of persons with physical disabilities, and consequently mobility limitations, helping them to overcome barriers constituted by physical distances between individuals, communities and institutions.

In addition to this, the European Union's strategies included the development of digital services, based on, along with the specific infrastructure of communications services, human capital. Thus, the European Disability Strategy (2010-2020) highlighted among the priority areas for joint action between the EU and EU countries - accessibility, participation, education and training, employment - in order to empower people with disabilities so that they can fully enjoy their rights and participate in society and the economy on an equal basis with others [4]. Two EU's priorities in the field of education are reducing early school leaving to less than $10 \%$ across EU member states [5] and reaching the target that $40 \%$ of young Europeans have a higher education qualification [6].

The textile sector by research-development activities and by its numerous projects and accomplishments in the bio-materials, biotechnologies and medical device, showed a steady focus, in close relation to the medical field, on disabled persons' quality of life and on the facilitation of their social and professional integration [7-8]. The textile materials used for healthcare and hygiene products are those commonly used on hospital wards for the care and hygiene of the patient and includes bedding, clothing, mattress covers, incontinence products, cloths and wipes.

Cerebral palsy (CP) is a group of non-progressive abnormalities of movement and posture, which results from an aggression on the brain during its developmental period, causing activity limitation, frequently accompanied by sensory, cognitive, behavioral disorders and, sometimes epilepsy.

Recent studies indicate a prevalence of CP from 1.5 to more than 4 per 1000 children [9], with an increase in the last decades [10]. According to World Health
Statistic, the high quality of prenatal care, skilled birth care and postnatal care of the mother and newborns, decreased the worldwide rate of death in the first month of life by over $40 \%$ in the last 17 years [11]. But, on the other hand, the improved rate of survival of preterm and low-birth-weight infants - both being consider risk factors for CP $[9,12]$ - raise concerns about the increased frequency of occurrence of neurodevelopmental sequelae, especially on CP.

Cerebral palsy was mentioned for the first time in 1843 by an English orthopedic surgeon named William Little in a series of lectures entitled "Human body deformities" and, as a result, CP was known for many years like "Little's Disease". In the early stages of the disease or at an earlier age it may not be obvious the neurodevelopmental delay due to the immaturity of the nervous system. Motor deficits in CP include weakness, fatigue, incoordination, spasticity, clonus, rigidity, and spasms. Spasticity is an increased muscle tone who can lead to muscle stiffness, functional impairment, and atrophy, followed by muscle fibrosis, contractures, and subsequent musculoskeletal deformities. McGillivray (2016) mentions that, in over $86 \%$ of the over 17 million patients diagnosed with $\mathrm{CP}$ worldwide, the predominant motor type of CP was spasticity [13]. It was reported a $30 \%$ higher incidence of CP in males than in females [14]. According to the topographic distribution of motor involvement: CP can be classified as monoplegia, diplegia, hemiplegia, triplegia, quadriplegia, and double hemiplegia [15]. Among the associated complications may be encountered: cognitive impairment, eating disorders, bladder and bowel dysfunctions sleep disturbances, visual and orthopedic abnormalities. It is well known that "not all children with CP are cognitively impaired, the commonest type (spastic diplegic CP) is characterized by normal cognition" [16].

Quality of life, defined as "the extent to which persons enjoy a good life by achieving a balance in their relations with themselves and with others through creating and sustaining adequate conditions and own potentials over the life course" [17], provides important information about the way in which the adolescent and his parent/caregiver perceive the activity limitations and the participation restrictions due to the impairments in body functions and structures.

A literature review from 1980 to 2007 performed by Viehweger to identify existing HRQoL scales in CP patients shown that is necessary to develop new scales and to improve the available ones, because the properties of existing scales "do not allow for its full and satisfying use" [18].

Livingstone et al. described well-being as having two components: an objective ("functional status" and "health status") and a subjective one ("QoL and HRQoL") [19].

Arnaud (2008) and Gilson (2014) point out that "grater severity of impairment was not always associated with poorer quality of life" [20-21], QoL being related rather to the way in which the individual feels that is accepted by the environment in which he carries out his activity (family, school, society). Studies indicated that "disabled children experience most of 
life as do non-disabled children", thus is needed to support social and educational policies that... ensure their right as citizens, rather than as disabled children, to participate fully in society" [3].

Pain is considered an important factor that depreciated the QoL due to its physical and psychological effects. Another element with negative impact on quality of life was parents' stress [22], generated by perception of children's illness (physical, socio-emotional and cognitive problems, financial strain etc.), they reporting lower results in all assessed domains. Mpundu-Kaambwa (2018) also highlighted the negative impact of children's chronic disease on QoL reported by parents/caregivers [23].

Berrin has shown in 2007 that, next to pain, fatigue also have a negative impact on one of the QoL domains: school functioning [24]. Teachers should consider these aspects and adapt curricular components to adolescents' potential so that adolescents with special needs can benefit from a quality education that will facilitate their integration into the labor market. In 2006 Varni - the PedsQL developer demonstrated that fatigue is inversely correlated with school functioning [25].

In addition to above mentioned comorbidities, sleep disturbances are frequently encountered in CP. They affect both the psycho-emotional status of the child and the compliance with the therapeutic-rehabilitative interventions, leading to a "decreased overall HRQoL" [26].

According to Majnemer, psychosocial well-being it doesn't appear to be correlated with motor and other activity limitation, these influencing only physical well-being [27].

Examining physical activity in adults with $\mathrm{CP}$, Waltersson discovered that adults who used to perform physical activity as adolescents had a double probability to do it as adults, too [28]. QoL had been positively influenced by physical activity performance but, aging and reducing frequency of participation had a negative effect on all QoL domains [29].

A cross-sectional cohort study which examined the HRQoL in children and adolescents with CP reported the higher rate of HRQoL in children, followed by adolescents and, in the end, parents. An explanation could be the way in which children feels the limitations and restrictions, which have different significance as the child becomes adolescent, while the parents/caregivers tend to compare their children with healthy children [30].

In 2018 Ozkan compared children's QoL and mothers' burden in different types of CP and established that the lowest children's QoL score was reached in quadriplegia, followed by hemiplegia and diplegia, and demonstrated the existence of a significant negative correlation between mothers' burden and child's QoL [31]. There have been found "positive correlations"... between parent physical health and the physical function of their children with CP... and between parent mental health and the emotional function... psychosocial function... and total healthrelated quality of life of their children" [32].
Our goal was to assess QoL of adolescents with CP - without major cognition impairment - and to find out if there is any discrepancy between adolescents' selfreport and parents' proxy-report and any correlation between the assessed dimensions (activities of daily living, school activities, movement and balance, pain and hurt, fatigue, eating, speech and communication).

\section{MATERIAL AND METHODS}

In the study, 162 patients diagnosed with CP and their parents/caregivers were assessed during hospitalization at the National Teaching Centre for Neuropsychomotor Rehabilitation in Children "Dr. Nicolae Robanescu" (NTCNRC), during 2018 using Pediatric Quality of Life Inventory PedsQL ${ }^{\mathrm{TM}} 3.0$ Cerebral Palsy Module (PedsQL CP), to determine health-related quality of life (HRQoL) dimensions specific to $\mathrm{CP}$.

The study has been approved by the Ethics Committee of NTCNRC under no. 9586/15.12.2017.

Written informed consent from parents/caregivers and adolescent assent were obtained prior to their participation to the study.

The selection of cases for setting up the patients' study group had as criteria for inclusion/exclusion the patients' age and their level of cooperation.

The group has the following characteristics:

- age ranging from 11 to 18 years;

- asymmetric distribution: $35 \%$ girls, $65 \%$ boys;

- all of them, even those with development disability, had an acceptable level of cooperation during the assessments and were users of medical textiles.

The criterion for inclusion/exclusion the adolescents' parents/caregivers in the study was only their level of cooperation.

PedsQL CP is a health-related quality-of-life instrument developed by Varniet et al. [25], which emphasizes the adolescent's perception. It has 2 components: adolescent self-report and parent proxy-report (to assess parents 'perceptions of their child's HRQoL), which consist of 35 items divided into seven subscales:

- Daily Activities (9 items),

- School Activities (4 items),

- Movement and Balance (5 items),

- Pain and Hurt (4 items),

- Fatigue (4 items),

- Eating Activities (5 items), and

- Speech and Communication (4 items)

to find out how much of a problem each item has been for adolescent during the past one month.

For adolescents who did not have the capacity for self-administration, but did have the capacity for selfreport, the PedsQL CP was interviewer-administered. Otherwise, the instrument was self-administered for both parents/caregivers and adolescents, excepting the ones who needed help in reading the items, which could choose between self-administration and interviewer-administration.

Knowing that "children and family members influence one another in transaction through development" 
[33], parents and adolescents were questioned separately so as not to influence each other's opinion and perception.

For both adolescents and parents/caregivers, responses are given on a 5-point Likert scale with: 0 (nevera problem), 1 (almost never a problem), 2 (sometimes a problem), 3 (often a problem), and 4 (almost always a problem). Each scale is then linearly transformed and reverse-scored to a 0-100 scale $(0=100,1=75,2=50,3=25,4=0)$, so that higher scores indicate lower problems and a better HRQoL. The statistical processing of primary data was performed with the Statistical Package for the Social Sciences IBM SPSS Statistics for Windows, Version24.

\section{RESULTS}

During the study, 162 adolescents with $\mathrm{CP}$ and their parents completed PedsQL CP. Almost two-thirds of the sample of adolescents was male. The CP types encountered in study group were hemiplegia (39\%), diplegia (31\%), quadriplegia $(22 \%)$, triplegia $(4 \%)$ and the mixed form (4\%) as shown in figure 1.

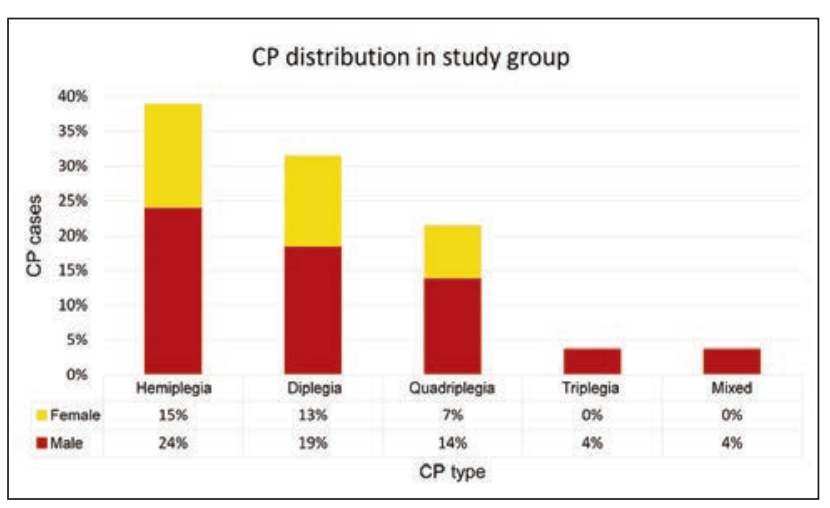

Fig. 1. Participants' characteristics
Both parents and adolescents reported how much of a problem each item from all 7 domains (ADL, school activity, movement and balance, pain and hurt, fatigue, eating activities, speech and communication) has been for adolescent during the past one month. The descriptive analysis for PedsQL CP is presented below in table 1 (adolescents' self-report parents' proxy-report).

There is a statistically significant difference between the answers of parents and children on the PEDsQL questionnaire for all the groups of variables, with the exception of School, where the responses were found to be not statistically different. Motor and cognitive impairments haven't been perceived by adolescents as a limitation regarding the school activities. An explanation of the discrepancies between adolescents' and parents' report regarding school activities, with parents reporting a lower QoL, could be the bullying phenomenon that disabled children are often subjected to, as mentioned in the literature, too [34]. In ADL domain adolescents have an average value of 585.5 (table 1), while parents have an average value of 486.57 . Table 2 states that this difference is statistically significant. These mean that adolescents and parents have different perception on adolescents' activities of daily living.

As we can see from the tables 3-5, none of the variables are significantly different for males and females. Quality of life statistics, although slightly different for the two groups (e.g.: ADL value for males is over 40 points higher than females), are not different enough to infer any kind of general, population valid effect.

Of all types of $\mathrm{CP}$, the adolescents with quadriplegia have the lowest QoL in all assessed domain, except for the fatigue. The ANOVA test shows that our groups are significantly different in their perceptions

Table 1

SCALE DESCRIPTIVE ANALYSIS FOR PEDSQL 4.0 GENERIC CORE SCALES PARENT PROXY-REPORT AND CHILD SELF-REPORT

\begin{tabular}{|l|l|c|c|c|c|}
\hline \multirow{2}{*}{\multicolumn{2}{|c|}{ Items }} & \multicolumn{4}{c|}{ Group statistics } \\
\cline { 3 - 6 } \multicolumn{2}{|c|}{ ADL } & N & Mean & Std. Deviation & Std. Error Mean \\
\hline \multirow{3}{*}{ School } & Children & 162 & 486.5741 & 258.80667 & 20.33377 \\
\cline { 2 - 6 } & Parents & 162 & 587.5000 & 256.41233 & 20.14566 \\
\cline { 2 - 6 } Balance & Children & 162 & 225.4630 & 127.55075 & 10.02133 \\
\hline \multirow{3}{*}{ Pain } & Parents & 162 & 252.7778 & 131.69936 & 10.34728 \\
\cline { 2 - 6 } & Children & 162 & 297.2222 & 126.46655 & 9.93615 \\
\hline \multirow{3}{*}{ Fatigue } & Parents & 162 & 402.7778 & 111.69919 & 8.77592 \\
\cline { 2 - 6 } & Children & 162 & 318.9815 & 100.88142 & 7.92599 \\
\hline \multirow{2}{*}{ Eating } & Parents & 162 & 375.0000 & 42.62359 & 3.34883 \\
\cline { 2 - 6 } & Children & 162 & 273.6111 & 127.08662 & 9.98487 \\
\hline \multirow{2}{*}{ Total } & Parents & 162 & 316.6667 & 88.85923 & 6.98144 \\
\cline { 2 - 6 } & Children & 162 & 367.5926 & 103.46815 & 8.12923 \\
\hline & Parents & 162 & 418.9815 & 93.82344 & 7.37147 \\
\cline { 2 - 6 } & Children & 162 & 0.6589 & 0.18364 & 0.01443 \\
\hline
\end{tabular}


SCALE DESCRIPTIVE ANALYSIS FOR PEDSQL 4.0 GENERIC CORE SCALES PARENT PROXY-REPORT AND CHILD SELF-REPORT

\begin{tabular}{|c|c|c|c|c|c|c|c|c|c|c|}
\hline \multirow{4}{*}{\multicolumn{2}{|c|}{ Items }} & \multicolumn{9}{|c|}{ Independent Samples Test } \\
\hline & & \multicolumn{2}{|c|}{$\begin{array}{l}\text { Levene's Test for } \\
\text { Equality of Variances }\end{array}$} & \multicolumn{7}{|c|}{ t-test for Equality of Means } \\
\hline & & \multirow[t]{2}{*}{$\mathrm{F}$} & \multirow{2}{*}{ Sig. } & \multirow{2}{*}{$\mathrm{t}$} & \multirow{2}{*}{ df } & \multirow{2}{*}{$\begin{array}{c}\text { Sig. } \\
\text { (2-tailed) }\end{array}$} & \multirow{2}{*}{$\begin{array}{c}\text { Mean } \\
\text { Difference }\end{array}$} & \multirow{2}{*}{$\begin{array}{l}\text { Std. Error } \\
\text { Difference }\end{array}$} & \multicolumn{2}{|c|}{$\begin{array}{l}\text { 95\% Confidence Interval } \\
\text { of the Difference }\end{array}$} \\
\hline & & & & & & & & & Lower & Upper \\
\hline \multirow[b]{2}{*}{ ADL } & \begin{tabular}{|l|} 
Equal \\
variances \\
assumed
\end{tabular} & 0.347 & 0.556 & -3.526 & 322 & 0.000 & -100.92593 & 28.62359 & -157.23879 & -44.61307 \\
\hline & $\begin{array}{l}\text { Equal } \\
\text { variances } \\
\text { not } \\
\text { assumed }\end{array}$ & & & -3.526 & 321.972 & 0.000 & -100.92593 & 28.62359 & -157.23880 & -44.61305 \\
\hline \multirow[b]{2}{*}{ School } & \begin{tabular}{|l|} 
Equal \\
variances \\
assumed
\end{tabular} & 1.640 & 0.201 & -1.896 & 322 & 0.059 & -27.31481 & 14.40463 & -55.65388 & 1.02425 \\
\hline & \begin{tabular}{|l} 
Equal \\
variances \\
not \\
assumed
\end{tabular} & & & -1.896 & 321.671 & 0.059 & -27.31481 & 14.40463 & -55.65399 & 1.02436 \\
\hline \multirow[b]{2}{*}{ Balance } & $\begin{array}{l}\text { Equal } \\
\text { variances } \\
\text { assumed }\end{array}$ & 3.351 & 0.068 & -7.962 & 322 & 0.000 & -105.55556 & 13.25684 & -131.63651 & -79.47460 \\
\hline & \begin{tabular}{|l} 
Equal \\
variances \\
not \\
assumed
\end{tabular} & & & -7.962 & 317.160 & 0.000 & -105.55556 & 13.25684 & -131.63802 & -79.47310 \\
\hline \multirow[b]{2}{*}{ Pain } & $\begin{array}{l}\text { Equal } \\
\text { variances } \\
\text { assumed }\end{array}$ & 123.685 & 0.000 & -6.510 & 322 & 0.000 & -56.01852 & 8.60442 & -72.94649 & -39.09054 \\
\hline & \begin{tabular}{|l|} 
Equal \\
variances \\
not \\
assumed
\end{tabular} & & & -6.510 & 216.707 & 0.000 & -56.01852 & 8.60442 & -72.97758 & -39.05946 \\
\hline \multirow[b]{2}{*}{ Fatigue } & $\begin{array}{l}\text { Equal } \\
\text { variances } \\
\text { assumed }\end{array}$ & 32.885 & 0.000 & -3.534 & 322 & 0.000 & -43.05556 & 12.18352 & -67.02490 & -19.08621 \\
\hline & \begin{tabular}{|l} 
Equal \\
variances \\
not \\
assumed
\end{tabular} & & & -3.534 & 288.054 & 0.000 & -43.05556 & 12.18352 & -67.03556 & -19.07555 \\
\hline \multirow[b]{2}{*}{ Eating } & $\begin{array}{l}\text { Equal } \\
\text { variances } \\
\text { assumed }\end{array}$ & 1.246 & 0.265 & -4.683 & 322 & 0.000 & -51.38889 & 10.97373 & -72.97816 & -29.79962 \\
\hline & $\begin{array}{l}\text { Equal } \\
\text { variances } \\
\text { not } \\
\text { assumed }\end{array}$ & & & -4.683 & 318.965 & 0.000 & -51.38889 & 10.97373 & -72.97893 & -29.79885 \\
\hline \multirow[b]{2}{*}{ Total } & $\begin{array}{l}\text { Equal } \\
\text { variances } \\
\text { assumed }\end{array}$ & 9.919 & 0.002 & -6.535 & 322 & 0.000 & -0.12011 & 0.01838 & -0.15626 & -0.08395 \\
\hline & $\begin{array}{l}\text { Equal } \\
\text { variances } \\
\text { not } \\
\text { assumed }\end{array}$ & & & -6.535 & 305.483 & 0.000 & -0.12011 & 0.01838 & -0.15627 & -0.08394 \\
\hline
\end{tabular}




\begin{tabular}{|c|c|c|c|c|c|}
\hline \multicolumn{6}{|c|}{ SCALE DESCRIPTIVE ANALYSIS FOR PEDSQL 4.0 GENERIC CORE SCALES PATIENT GENDER } \\
\hline \multicolumn{6}{|c|}{ Group Statistics } \\
\hline Items & Gender & $\mathbf{N}$ & Mean & Std. Deviation & Std. Error Mean \\
\hline \multirow{2}{*}{ ADL } & female & 60 & 560.0000 & 251.02333 & 32.40697 \\
\hline & male & 102 & 603.6765 & 259.38801 & 25.68324 \\
\hline \multirow{2}{*}{ School } & female & 60 & 253.7500 & 133.94479 & 17.29220 \\
\hline & male & 102 & 252.2059 & 131.02334 & 12.97324 \\
\hline \multirow{2}{*}{ Balance } & female & 60 & 417.5000 & 94.02713 & 12.13885 \\
\hline & male & 102 & 394.1176 & 120.49693 & 11.93097 \\
\hline \multirow{2}{*}{ Pain } & female & 60 & 381.2500 & 43.57562 & 5.62559 \\
\hline & male & 102 & 371.3235 & 41.83257 & 4.14204 \\
\hline \multirow{2}{*}{ Fatigue } & female & 60 & 315.0000 & 74.10483 & 9.56689 \\
\hline & male & 102 & 317.6471 & 96.83022 & 9.58762 \\
\hline \multirow{2}{*}{ Eating } & female & 60 & 422.5000 & 84.71037 & 10.93606 \\
\hline & male & 102 & 416.9118 & 99.13998 & 9.81632 \\
\hline \multirow{2}{*}{ Total } & female & 60 & 0.7804 & 0.13861 & 0.01789 \\
\hline & male & 102 & 0.7782 & 0.14916 & 0.01477 \\
\hline
\end{tabular}

Table 4

\begin{tabular}{|c|c|c|c|c|c|c|c|c|c|c|}
\hline \multicolumn{11}{|c|}{ SCALE DESCRIPTIVE ANALYSIS FOR PEDSQL 4.0 GENERIC CORE SCALES PATIENT GENDER } \\
\hline \multirow{4}{*}{\multicolumn{2}{|c|}{ Items }} & \multicolumn{9}{|c|}{ Independent Samples Test } \\
\hline & & \multicolumn{2}{|c|}{$\begin{array}{c}\text { Levene's Test for } \\
\text { Equality of Variances }\end{array}$} & \multicolumn{7}{|c|}{ t-test for Equality of Means } \\
\hline & & \multirow[t]{2}{*}{$\mathrm{F}$} & \multirow{2}{*}{ Sig. } & \multirow{2}{*}{$\mathrm{t}$} & \multirow{2}{*}{ df } & \multirow{2}{*}{$\begin{array}{c}\text { Sig. } \\
\text { (2-tailed) }\end{array}$} & \multirow{2}{*}{$\begin{array}{c}\text { Mean } \\
\text { Difference }\end{array}$} & \multirow{2}{*}{$\begin{array}{l}\text { Std. Error } \\
\text { Difference }\end{array}$} & \multicolumn{2}{|c|}{$\begin{array}{c}95 \% \text { Confidence Interva } \\
\text { of the Difference }\end{array}$} \\
\hline & & & & & & & & & Lower & Upper \\
\hline 1 & 2 & 3 & 4 & 5 & 6 & 7 & 8 & 9 & 10 & 11 \\
\hline \multirow[b]{2}{*}{ ADL } & $\begin{array}{l}\text { Equal } \\
\text { variances } \\
\text { assumed }\end{array}$ & 1.013 & 0.316 & -1.047 & 160 & 0.297 & -43.67647 & 41.70520 & -126.04014 & 38.68720 \\
\hline & \begin{tabular}{|l|} 
Equal \\
variances \\
not \\
assumed
\end{tabular} & & & -1.056 & 127.100 & 0.293 & -43.67647 & 41.35022 & -125.50047 & 38.14753 \\
\hline \multirow[b]{2}{*}{ School } & $\begin{array}{l}\text { Equal } \\
\text { variances } \\
\text { assumed }\end{array}$ & 0.000 & 0.999 & 0.072 & 160 & 0.943 & 1.54412 & 21.49371 & -40.90384 & 43.99208 \\
\hline & \begin{tabular}{|l|} 
Equal \\
variances \\
not \\
assumed
\end{tabular} & & & .071 & 121.604 & 0.943 & 1.54412 & 21.61771 & -41.25169 & 44.33992 \\
\hline \multirow[b]{2}{*}{ Balance } & $\begin{array}{l}\text { Equal } \\
\text { variances } \\
\text { assumed }\end{array}$ & 6.268 & 0.013 & 1.289 & 160 & 0.199 & 23.38235 & 18.13596 & -12.43437 & 59.19908 \\
\hline & \begin{tabular}{|l|} 
Equal \\
variances \\
not \\
assumed
\end{tabular} & & & 1.374 & 147.593 & 0.172 & 23.38235 & 17.02057 & -10.25315 & 57.01785 \\
\hline \multirow[b]{2}{*}{ Pain } & $\begin{array}{l}\text { Equal } \\
\text { variances } \\
\text { assumed }\end{array}$ & 0.908 & 0.342 & 1.436 & 160 & 0.153 & 9.92647 & 6.91200 & -3.72404 & 23.57698 \\
\hline & $\begin{array}{l}\text { Equal } \\
\text { variances } \\
\text { not } \\
\text { assumed }\end{array}$ & & & 1.421 & 119.751 & 0.158 & 9.92647 & 6.98597 & -3.90555 & 23.75849 \\
\hline
\end{tabular}


Table 4 (continuation)

\begin{tabular}{|c|c|c|c|c|c|c|c|c|c|c|}
\hline 1 & 2 & 3 & 4 & 5 & 6 & 7 & 8 & 9 & 10 & 11 \\
\hline \multirow[b]{2}{*}{ Fatigue } & $\begin{array}{l}\text { Equal } \\
\text { variances } \\
\text { assumed }\end{array}$ & 2.332 & 0.129 & -0.183 & 160 & 0.855 & -2.64706 & 14.50080 & -31.28472 & 25.99060 \\
\hline & $\begin{array}{l}\text { Equal } \\
\text { variances } \\
\text { not } \\
\text { assumed }\end{array}$ & & & -0.195 & 149.144 & 0.845 & -2.64706 & 13.54429 & -29.41055 & 24.11643 \\
\hline \multirow[b]{2}{*}{ Eating } & $\begin{array}{l}\text { Equal } \\
\text { variances } \\
\text { assumed }\end{array}$ & 1.135 & 0.288 & 0.365 & 160 & 0.716 & 5.58824 & 15.30613 & -24.63986 & 35.81633 \\
\hline & $\begin{array}{l}\text { Equal } \\
\text { variances } \\
\text { not } \\
\text { assumed }\end{array}$ & & & 0.380 & 139.481 & 0.704 & 5.58824 & 14.69550 & -23.46649 & 34.64296 \\
\hline \multirow[b]{2}{*}{ Total } & $\begin{array}{l}\text { Equal } \\
\text { variances } \\
\text { assumed }\end{array}$ & 1.414 & 0.236 & 0.093 & 160 & 0.926 & 0.00221 & 0.02365 & -0.04450 & 0.04891 \\
\hline & \begin{tabular}{l|} 
Equal \\
variances \\
not \\
assumed
\end{tabular} & & & 0.095 & 131.198 & 0.924 & 0.00221 & 0.02320 & -0.04369 & 0.04811 \\
\hline
\end{tabular}

Table 5

DSCALE DESCRIPTIVE ANALYSIS FOR PEDSQL 4.0 GENERIC CORE SCALES CEREBRAL PALSY TYPE

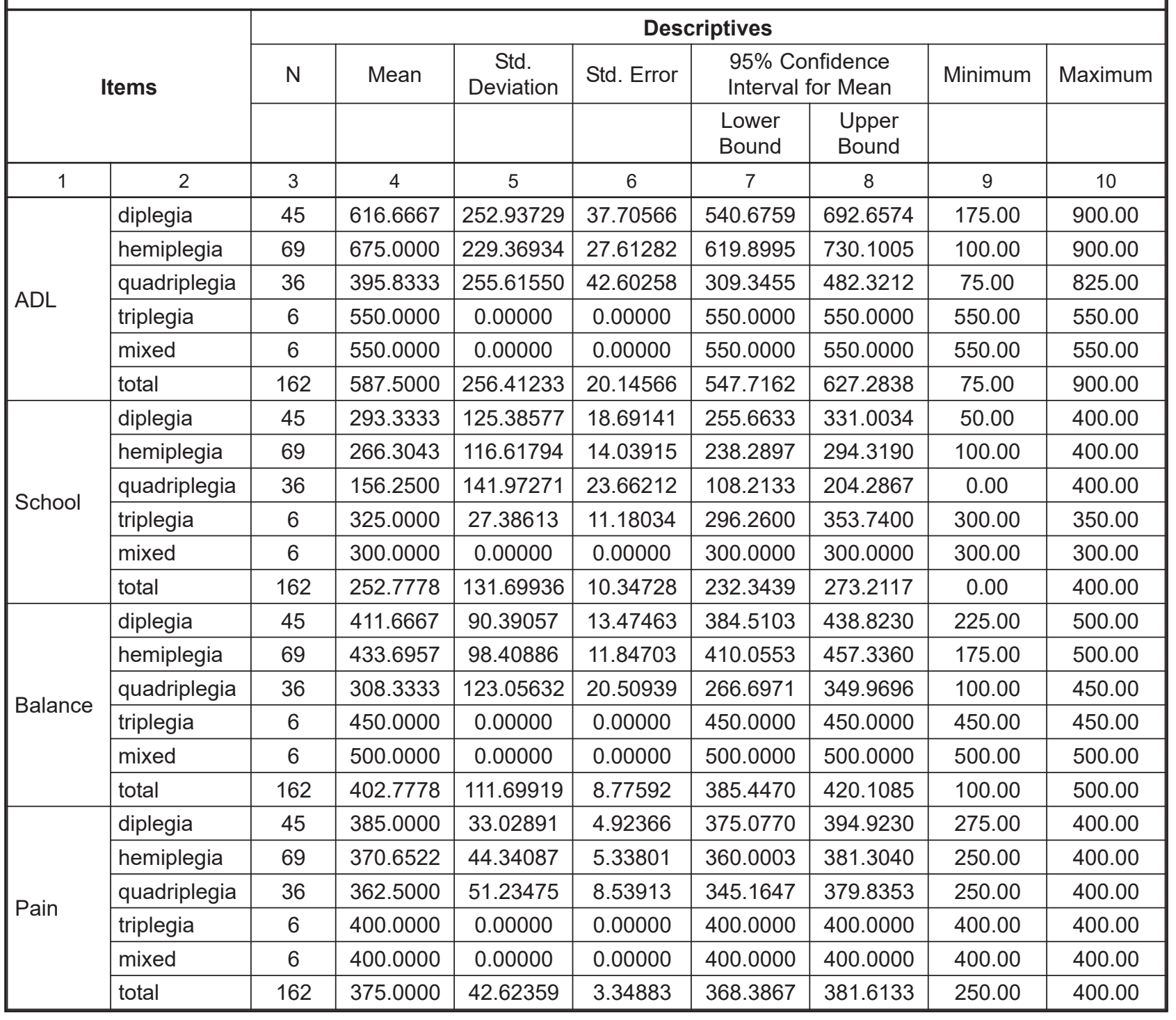




\begin{tabular}{|c|l|c|c|c|c|c|c|c|c|}
\hline 1 & \multicolumn{1}{|c|}{2} & 3 & 4 & 5 & 6 & 7 & 8 & 9 & 10 \\
\hline \multirow{5}{*}{ Fatigue } & diplegia & 45 & 358.3333 & 63.06562 & 9.40127 & 339.3863 & 377.2803 & 225.00 & 400.00 \\
\cline { 2 - 10 } & hemiplegia & 69 & 293.4783 & 104.81533 & 12.61828 & 268.2989 & 318.6577 & 50.00 & 400.00 \\
\cline { 2 - 10 } & quadriplegia & 36 & 314.5833 & 78.46177 & 13.07696 & 288.0357 & 341.1310 & 175.00 & 400.00 \\
\cline { 2 - 10 } & triplegia & 6 & 300.0000 & 54.77226 & 22.36068 & 242.5200 & 357.4800 & 250.00 & 350.00 \\
\cline { 2 - 10 } & mixed & 6 & 300.0000 & 0.00000 & 0.00000 & 300.0000 & 300.0000 & 300.00 & 300.00 \\
\cline { 2 - 10 } & total & 162 & 316.6667 & 88.85923 & 6.98144 & 302.8797 & 330.4537 & 50.00 & 400.00 \\
\hline \multirow{5}{*}{ Eating } & diplegia & 45 & 435.0000 & 90.35913 & 13.46994 & 407.8531 & 462.1469 & 200.00 & 500.00 \\
\cline { 2 - 10 } & hemiplegia & 69 & 429.3478 & 74.87201 & 9.01353 & 411.3616 & 447.3340 & 200.00 & 500.00 \\
\cline { 2 - 10 } & quadriplegia & 36 & 366.6667 & 119.07381 & 19.84563 & 326.3779 & 406.9554 & 75.00 & 500.00 \\
\cline { 2 - 10 } & triplegia & 6 & 412.5000 & 68.46532 & 27.95085 & 340.6501 & 484.3499 & 350.00 & 475.00 \\
\cline { 2 - 10 } & mixed & 6 & 500.0000 & 0.00000 & 0.00000 & 500.0000 & 500.0000 & 500.00 & 500.00 \\
\cline { 2 - 10 } & total & 162 & 418.9815 & 93.82344 & 7.37147 & 404.4243 & 433.5387 & 75.00 & 500.00 \\
\hline \multirow{5}{*}{} & diplegia & 45 & 0.8286 & 0.12683 & 0.01891 & 0.7905 & 0.8667 & 0.57 & 0.96 \\
\cline { 2 - 10 } & hemiplegia & 69 & 0.8056 & 0.12047 & 0.01450 & 0.7766 & 0.8345 & 0.56 & 0.99 \\
\cline { 2 - 10 } & quadriplegia & 36 & 0.6548 & 0.16536 & 0.02756 & 0.5988 & 0.7107 & 0.44 & 0.96 \\
\cline { 2 - 10 } & triplegia & 6 & 0.8107 & 0.01174 & 0.00479 & 0.7984 & 0.8230 & 0.80 & 0.82 \\
\cline { 2 - 9 } & mixed & 6 & 0.8143 & 0.00000 & 0.00000 & 0.8143 & 0.8143 & 0.81 & 0.81 \\
\cline { 2 - 9 } & total & 162 & 0.7790 & 0.14491 & 0.01139 & 0.7565 & 0.8015 & 0.44 & 0.99 \\
\hline
\end{tabular}

of the PedsQL 4.0 Generic Core Scales, differences that we can analyze from the table 6 results. Thus, for Pain scores, mixed and triplegia results are significantly higher (the mean score is 400 ) then quadriplegia patients (mean score is 362 ).
The reliability and internal consistency analysis followed that the items corresponding to each construct have a Cronbach's Alpha value over 0.7 and a composite reliability over 0.7 . The Cattel Scree plot and the Total Variance Table resulted from the exploratory

SCALE DESCRIPTIVE ANALYSIS FOR PEDSQL 4.0 GENERIC CORE SCALES CEREBRAL PALSY TYPE

\begin{tabular}{|c|c|c|c|c|c|c|}
\hline & \multirow{2}{*}{ Items } & \multicolumn{5}{|c|}{ ANOVA } \\
\hline & & Sum of Squares & df & Mean Square & $\mathrm{F}$ & Sig. \\
\hline \multirow{3}{*}{ ADL } & Between Groups & 1905937.500 & 4 & 476484.375 & 8.619 & 0.000 \\
\hline & Within Groups & 8679375.000 & 157 & 55282.643 & & \\
\hline & Total & 10585312.500 & 161 & & & \\
\hline \multirow{3}{*}{ School } & Between Groups & 466748.641 & 4 & 116687.160 & 7.877 & 0.000 \\
\hline & Within Groups & 2325751.359 & 157 & 14813.703 & & \\
\hline & Total & 2792500.000 & 161 & & & \\
\hline \multirow{3}{*}{ Balance } & Between Groups & 460717.391 & 4 & 115179.348 & 11.681 & 0.000 \\
\hline & Within Groups & 1548032.609 & 157 & 9860.080 & & \\
\hline & Total & 2008750.000 & 161 & & & \\
\hline \multirow{3}{*}{ Pain } & Between Groups & 18929.348 & 4 & 4732.337 & 2.716 & 0.032 \\
\hline & Within Groups & 273570.652 & 157 & 1742.488 & & \\
\hline & Total & 292500.000 & 161 & & & \\
\hline \multirow{3}{*}{ Fatigue } & Between Groups & 118716.033 & 4 & 29679.008 & 4.043 & 0.004 \\
\hline & Within Groups & 1152533.967 & 157 & 7340.981 & & \\
\hline & Total & 1271250.000 & 161 & & & \\
\hline \multirow{3}{*}{ Eating } & Between Groups & 157123.792 & 4 & 39280.948 & 4.894 & 0.001 \\
\hline & Within Groups & 1260133.152 & 157 & 8026.326 & & \\
\hline & Total & 1417256.944 & 161 & & & \\
\hline \multirow{3}{*}{ Total } & Between Groups & 0.729 & 4 & 0.182 & 10.781 & 0.000 \\
\hline & Within Groups & 2.652 & 157 & 0.017 & & \\
\hline & Total & 3.381 & 161 & & & \\
\hline
\end{tabular}


factor analysis done with SPSS Statistics using an oblique Promax rotation shows that all seven latent variables or constructs have eigenvalues greater than one, and the largest covariance explained by one factor is $28.845 \%$, thus common method bias not being a concern [34]. Only 14 of the all 35 variables measured have a significant effect on the result. One item of the speech and communication domain - how difficult is for other people to understand the patient when he speaks (Var 35) - has the greatest influence on QoL. It is followed by ability to button his/her own shirt (Var 02), ability to use scissors (Var 11) and the ability to cut his/her food (Var 31). For school activities there was no statistically significant difference, so parents and children have similar perceptions regarding this domain (table 7).

Table 7

\begin{tabular}{|c|c|c|}
\hline \multicolumn{3}{|c|}{ RELIABILITY ANALYSIS } \\
\hline $\begin{array}{c}\text { Cronbach's } \\
\text { Alpha }\end{array}$ & $\begin{array}{c}\text { Cronbach's Alpha Based } \\
\text { on Standardized Items }\end{array}$ & N of Items \\
\hline 0.714 & 0.850 & 7 \\
\hline
\end{tabular}

\section{CONCLUSIONS}

The research emphasized the existence of discrepancies between adolescents' and parents' reports regarding the QoL of adolescents' with $\mathrm{CP}$, with adolescents' reporting a higher QoL than did their parents, as it is also reported in the literature [35]. One explanation for these differences may be that parents relate to the performance of healthy children and the restrictions and limitations - mainly the motor ones - their children are encountered, are perceived to have a negative impact on the ability of children to integrate into family, school and social life. The psychological and social burden of the parents increases the child's psychological discomfort, which can lead to a lower compliance with rehabilitation treatment.

Both parents and children should be advised and encouraged, so that the latter learn new skills that will make possible the appearance of a degree of comfort reflected in physical and financial independence and social inclusion too.

Future work should explore factors that led to these different perceptions of QoL.

\section{ACKNOWLEDGEMENT}

This research was supported financially by the project CNFIS-FDI-2018-0582 - Supporting Excellence Research within The Bucharest University of Economic Studies in the context of the principles of sustainable development and open research. 6 . Supporting field research excellence in universities Beneficiary: The Bucharest University of Economic Studies. We would like to thank Prof. Varni for permission to use the PedsQL ${ }^{\mathrm{TM}} 3.0$ Cerebral Palsy Module (PedsQL TM, Copyright @ 1998 JW Varni, Ph.D. All rights reserved), and for his valuable help with the translation of the PedsQL ${ }^{\mathrm{TM}}$ to Romanian.

\section{AUTHORS CONTRIBUTION}

All the authors have contributed equally to the realization of this work and have approved of its publication.

\section{RECOGNITION}

The main author thanks to all the co-authors for the excellent collaboration and support. The present study is being linked to the whole of the PhD work: "Researches on integrated modes for the development of digital and preparatory abilities for writing, in children with cerebral palsy".

\section{REFERENCES}

[1] Nathan, A.J., Scobell, A., How China sees America, In: Foreign Aff., 2012, 91, 5

[2] WHO, WHOQOL: measuring quality of life, In: Psychol Med, 1998

[3] Dickinson, H.O., Parkinson, K.N., Ravens-sieberer, U., Schirripa, G., Thyen, U., Self-reported quality of life of 8 12-year-old children with cerebral palsy: a cross-sectional European study Already Registered? Please Login Already a Print Subscriber? Have a Free Trial Code?, In: Lancet, 2013, 369, 9580, 11-12

[4] European Comission, European Disability Strategy (2010-2020), Available: https://eur-lex.europa.eu/legalcontent/EN/TXT/?uri=LEGISSUM:em0047

[5] European Comission, Education and Training Policies. Early school leaving, Available: https://ec.europa.eu/ education/policies/school/early-school-leaving_en.

[6] European Comission, Education and Training. Higher education policy, Available: https://ec.europa.eu/education/ policies/higher-education/about-higher-education-policy_en.

[7] Rudolf, A., Stjepanovič, Z., Cupar, A., Designing the functional garments for people with physical disabilities or kyphosis by using computer simulation techniques, In: Industria Textila, 2019, 70, 2, 182-191, http://doi.org/ 10.35530/IT.070.02.1592

[8] Hong, Y., Bruniaux, P., Zhang, J., Liu, K., Dong, M., Chen, Y., Application of 3D-TO-2D garment design for atypical morphology: a design case for physically disabled people with scoliosis, In: Industria Textila, 2018, 69, 1, 59-64, http://doi.org/10.35530/IT.069.01.1377

[9] Stavsky, M., Mor, O., Mastrolia, S.A., Greenbaum, S., Than, N.G., Erez, O., Cerebral palsy-trends in epidemiology and recent development in prenatal mechanisms of disease, treatment, and prevention, In: Front. Pediatr., 2017, $5,1-10$

[10] Van Naarden Braun, K., Doernberg, N., Schieve, L., Christensen, D., Goodman, A., Yeargin-Allsopp, M., Birth prevalence of cerebral palsy: A population-based study, In: Pediatrics, 2016

[11] World Health Statistic, Monitoring Health for the SDGs, In: World Heal. Stat., 2019.

[12] Vincer, M.J., Allen, A.C., Allen, V.M., Baskett, T.F., O'Connell, C.M., Trends in the prevalence of cerebral palsy among very preterm infants (<31 weeks' gestational age), In: Paediatr. Child Heal., 2014, 19, 4, 185-189 
[13] McGillivray, A., General Movements Screening Guideline Women and Babies: General Movements Assessments (GMA) and other assessment modalities for prediction of cerebral palsy and adverse early neurodevelopment in high-risk infants, 2011

[14] Jarvis, S.N., et al., Case gender and severity in cerebral palsy varies with intrauterine growth, In: Arch. Dis. Child., 2005, 90, 5, 474-479

[15] Wiley, S., Lanphear, N.E., Cerebral palsy, In: Pediatric Clinical Advisor, 2007

[16] Jan, M.M.S., Cerebral palsy: Comprehensive review and update, In: Ann. Saudi Med., 2006, 26, 2, 123-132

[17] Vaarama, M., Pieper, R., Quality of Life and Quality of Care: an Integrated Model, In: Encyclopedia of Quality of Life and Well-Being Research, 2014

[18] Viehweger, E., et al., Measuring quality of life in cerebral palsy children, In: Ann. Readapt. Med. Phys., 2008, 51, 2, 129-137

[19] Livingston, M.H., Rosenbaum, P.L., Russell, D.J., Palisano, R.J., Quality of life among adolescents with cerebral palsy: What does the literature tell us?, In: Dev. Med. Child Neurol., 2007, 49, 3, 225-231

[20] Arnaud, C., et al., Parent-reported quality of life of children with cerebral palsy in Europe, In: Pediatrics, 2008, 121, 1, 54-64

[21] Gilson, K.M., Davis, E., Reddihough, D., Graham, K., Waters, E., Quality of life in children with cerebral palsy: Implications for practice, In: J. Child Neurol., 2014, 29, 8, 1134-1140

[22] Colver, A., et al., Self-reported quality of life of adolescents with cerebral palsy: A cross-sectional and longitudinal analysis, In: Lancet, 2015, 385, 9969, 705-716

[23] Mpundu-Kaambwa, C., Chen, G., Huynh, E., Russo, R., Ratcliffe, J., A review of preference-based measures for the assessment of quality of life in children and adolescents with cerebral palsy, In: Qual. Life Res., 2018, 27, 7, 1781-1799

[24] Berrin, S. J., et al., Pain, fatigue, and school functioning in children with cerebral palsy: A path-analytic model, In: J. Pediatr. Psychol., 2007, 32, 3, 330-337

[25] Varni, J.W., et al., The PedsQL in pediatric cerebral palsy: Reliability, validity, and sensitivity of the Generic Core Scales and Cerebral Palsy Module, In: Dev. Med. Child Neurol., 2006, 48, 6, 442-449

[26] Horwood, L., Li, P., Mok, E., Oskoui, M., Shevell, M., Constantin, E., Health-related quality of life in Canadian children with cerebral palsy: what role does sleep play?, In: Sleep Med., 2019, 54, 213-222

[27] Shikako-Thomas, K., Majnemer, A., Law, M., Lach, L., Determinants of participation in leisure activities in children and youth with cerebral palsy: Systematic review, In: Phys. Occup. Ther. Pediatr., 2008

[28] Waltersson, L., Rodby-Bousquet, E., Physical Activity in Adolescents and Young Adults with Cerebral Palsy, In: Biomed Res. Int., 2017

[29] Omura, J., Fuentes, M., Bjornson, K., Participation in Daily Life: Influence on Quality of Life in Ambulatory Children with Cerebral Palsy, In: PM R, 2018, 10, 11, 1185-1191

[30] Radsel, A., Osredkar, D., Neubauer, D., Health-related quality of life in children and adolescents with cerebral palsy, In: Zdr. Varst., 2017, 56, 1, 1-10

[31] Ozkan, Y., Child's quality of life and mother's burden in spastic cerebral palsy: a topographical classification perspective, In: J. Int. Med. Res., 2018, 46, 8, 3131-3137

[32] Murphy, N., Caplin, D.A., Christian, B.J., Luther, B.L., Holobkov, R., Young, P.C., The Function of Parents and Their Children with Cerebral Palsy, In: PM R, 2011, 3, 2, 98-104

[33] Wallander, J.L., Varni, J.W., Effects of Pediatric Chronic Physical Disorders on Child and Family Adjustment, In: J. Child Psychol. Psychiatry, 1998, 39, 1, 29-46

[34] Waasdorp, T.E., Bradshaw, C.P., Duong, J., The Link Between Parents' Perceptions of the School and Their Responses to School Bullying: Variation by Child Characteristics and the Forms of Victimization, In: J. Educ. Psychol., 2011

[35] Longo, E., Badia, M., Begoña Orgaz, M., Gómez-Vela, M., Comparing parent and child reports of health-related quality of life and their relationship with leisure participation in children and adolescents with Cerebral Palsy, In: Res. Dev. Disabil., 2017

\section{Authors:}

\section{CORINA SPOREA ${ }^{1}$, MARGARETA STELA FLORESCU ${ }^{2}$, OLGUTA ANCA ORZAN ${ }^{3}$, IOAN CRISTESCU 4}

${ }^{1}$ Centrul Național Clinic de Recuperare Neuropsihomotorie pentru Copii „Doctor Nicolae Robănescu”, Soldat Dumitru Mincă Street, no. 44, 041408, Bucharest, Romania e-mail: corina.sporea@gmail.com

${ }^{2}$ Academia de Studii Economice București, Facultatea de Administratie și Management Public, Piața Romana, no. 6, 010374, Bucharest, Romania e-mail: margareta.florescu@ari.ase.ro

${ }^{3}$ Spitalul Universitar de Urgenţă Elias, Bd. Mărăşti, no. 17, 011461, Bucharest, Romania

${ }^{4}$ Spitalul Clinic de Urgență București, Calea Floreasca, no. 8, 014461, Bucharest, Romania e-mail: ioancristescu@yahoo.com

\section{Corresponding author:}

OLGUTA ANCA ORZAN

e-mail: orzan@yahoo.com 